\title{
Aluminum Hydride, A1H3, As a Hydrogen Storage Compound
}

\author{
Jason Graetz, James Reilly, G. Sandrock, John Johnson, \\ Wei Min Zhou and James Wegrzyn
}

November 2006

\author{
Energy Science and Technology Department \\ Energy Resources Division
Brookhaven National Laboratory
P.O. Box 5000
Upton, NY 11973-5000
www.bnl.gov




\section{DISCLAIMER}

This report was prepared as an account of work sponsored by an agency of the United States Government. Neither the United States Government nor any agency thereof, nor any of their employees, nor any of their contractors, subcontractors, or their employees, makes any warranty, express or implied, or assumes any legal liability or responsibility for the accuracy, completeness, or any third party's use or the results of such use of any information, apparatus, product, or process disclosed, or represents that its use would not infringe privately owned rights. Reference herein to any specific commercial product, process, or service by trade name, trademark, manufacturer, or otherwise, does not necessarily constitute or imply its endorsement, recommendation, or favoring by the United States Government or any agency thereof or its contractors or subcontractors. The views and opinions of authors expressed herein do not necessarily state or reflect those of the United States Government or any agency thereof. 


\title{
ALUMINUM HYDRIDE, $\mathrm{AlH}_{3}$, AS A HYDROGEN STORAGE COMPOUND
}

\author{
Jason Graetz, James Reilly, G. Sandrock, John Johnson, Wei Min Zhou and James Wegrzyn \\ Department of Energy Science and Technology \\ Brookhaven National Laboratory \\ Upton NY, U.S.A.
}

Keywords: Aluminum Hydride, Kinetics, Thermodynamics

\begin{abstract}
Aluminum hydride is a covalent, binary hydride that has been known for more than 60 years and is an attractive medium for on-board automotive hydrogen storage, since it contains $10.1 \%$ by wt. hydrogen with a density of $1.48 \mathrm{~g} / \mathrm{ml}$. There are at least 7 non-solvated $\mathrm{AlH}_{3}$ phases, namely $\alpha, \alpha, \beta, \gamma, \delta, \varepsilon$ and $\zeta$. The properties of $\alpha-\mathrm{AlH}_{3}$, obtained from the Dow Chemical Co. in 1980, have been previously reported. Here we present a description of the thermodynamic and kinetic properties of freshly prepared $\alpha, \beta$ and $\gamma$ phases of $\mathrm{AlH}_{3}$. In all cases the decomposition kinetics are appreciable below $100^{\circ} \mathrm{C}$ and all will meet the DOE 2010 gravimetric and volumetric vehicular system targets $\left(6 \mathrm{wt} \% \mathrm{H}_{2}\right.$ and $\left.0.045 \mathrm{~kg} / \mathrm{L}\right)$. However, further research will be required to develop an efficient and economical process to regenerate $\mathrm{AlH}_{3}$ from the spent $\mathrm{Al}$ powder.
\end{abstract}

\section{Introduction}

Aluminum hydride, $\mathrm{AlH}_{3}$, is the most well known alane. It is a covalent, binary hydride that has been known for more than 60 years. $\mathrm{AlH}_{3}$ is a very attractive medium for on-board automotive hydrogen storage, since it contains $10.1 \%$ by wt. hydrogen with a density of 1.48 $\mathrm{g} / \mathrm{ml}$. It was first prepared in an ether solvated form by Finholt et al. [1]. Non-solvated $\mathrm{AlH}_{3}$ was prepared Brower et al. [2] using an organometallic synthesis route. They noted the existence of at least 7 non-solvated phases, namely $\alpha, \alpha, \beta, \gamma, \delta, \varepsilon$ and $\xi$. The structure of $\alpha-\mathrm{AlH}_{3}$ was later determined by Turley and Rinn [3], they identified the space group as $\mathrm{R} \overline{3} \mathrm{c}$ with 6 molecules/unit cell with $\mathrm{a}=4.449 \AA$ and $\mathrm{B}=11.804 \AA$. The determination of the remaining structures is yet to be reported. All of the known $\mathrm{AlH}_{3}$ phases are thermodynamically unstable with an equilibrium decomposition pressure of many kbar at room temperature although they are usually metastable and do not decompose rapidly at room temperature. The decomposition of $\mathrm{AlH}_{3}$ occurs in a single step, as shown below:

$$
\mathrm{AlH}_{3} \rightarrow \mathrm{Al}+3 / 2 \mathrm{H}_{2}
$$

It is the purpose of this paper to summarize our recent work concerning thermodynamics and decomposition kinetics with respect to selected alane phases.

$\alpha-\mathrm{AlH}_{3}$ is not currently commercially available, but was made by the DOW Chemical Co. about 25 years ago. At that time BNL acquired $1 \mathrm{~kg}$ of non-solvated $\alpha-\mathrm{AlH}_{3}$ from DOW Chemical, which we designate as aged $\alpha-\mathrm{AlH}_{3}$. As received, the DOW material contained 8.3 $\mathrm{wt} \%$ hydrogen, which is lower than the $10.1 \mathrm{wt} \%$ expected of pure $\mathrm{AlH}_{3}$. It can be noted that the material has lost very little hydrogen over the past 25 years, having been stored during this time in air at ambient temperature and pressure. The original synthesis was aimed at producing a 
product suitable for a rocket fuel, not pyrophoric and that could be stored indefinitely without decomposition. This relatively inert quality is generally assumed to be due to the presence of a surface oxide layer, which acts as a kinetic barrier to decomposition. However, a "catalyst" introduced by ball milling can alter this surface barrier and lead to decomposition kinetics at $100^{\circ} \mathrm{C}$ which may be adequate for use in $\mathrm{H}$-powered vehicles. The freshly prepared $\alpha, \beta$ and $\gamma$ polymorphs are much more reactive and have a hydrogen content $>9.5 \mathrm{wt} . \%$. It is not necessary to ball mill freshly prepared material or add a catalyst in order to attain decomposition rates suitable for practical applications at low temperatures $\left(<100^{\circ} \mathrm{C}\right)$.

\section{Synthesis of $\mathrm{AlH}_{3}$}

The syntheses, based on Brower's original methods, were previously described in detail [4]; for convenience, a brief summary is presented here. $\mathrm{AlH}_{3}$ was synthesized via an ethereal reaction of $\mathrm{AlCl}_{3}$ with $\mathrm{LiAlH}_{4}$ to produce an etherated species of aluminum hydride, $\left.\mathrm{AlH}_{3} \cdot\left[\mathrm{C}_{2} \mathrm{H}_{5}\right)_{2} \mathrm{O}\right]$. The removal of the associated ether is accomplished by heating the solvated $\mathrm{AlH}_{3}$ in the presence of a complex metal hydride $\left(\mathrm{LiAlH}_{4}, \mathrm{LiBH}_{4}\right)$ under vacuum. The synthesis is extremely sensitive to the desolvating conditions (e.g. temperature and time) and small alterations can lead to the precipitation of a different $\mathrm{AlH}_{3}$ polymorph. $\gamma-\mathrm{AlH}_{3}$ forms in the presence of excess $\mathrm{LiAlH}_{4}$, while $\beta-\mathrm{AlH}_{3}$ forms in the presence of $\mathrm{LiAlH}_{4}$ and $\mathrm{LiBH}_{4}$. In both cases, a slightly higher temperature $\left(\sim 70^{\circ} \mathrm{C}\right)$ and/or a longer heating time will lead to the formation of $\alpha-\mathrm{AlH}_{3}$.

\section{Thermodynamics and Phase Stability}

Sinke et al. [5], employing a calorimetric method, measured $\Delta \mathrm{H}_{f}$ to be $-11.4+/-0.8 \mathrm{~kJ} / \mathrm{mol}$ $\mathrm{AlH}_{3}$ and $\Delta \mathrm{G}_{f 298 \mathrm{~K}}$ to be $46.4+/-11 \mathrm{~kJ} / \mathrm{mol} \mathrm{AlH}_{3}$. The $\mathrm{AlH}_{3}$ phase measured was not identified but was supplied by the Dow Chemical Co. and was likely the $\alpha$ phase. Baranowski and Tkacz[6] measured the equilibrium dissociation plateau pressure of aged $\alpha-\mathrm{AlH}_{3}$ (Dow) to be $\sim 10 \mathrm{kbar}$ at $150^{\circ} \mathrm{C}$; however this value seems much too low in view of Sinke's data and recent values obtained by Graetz and Reilly [7] using DSC (differential scanning calorimetry) for freshly prepared $\alpha, \beta$ and $\gamma$ phases of $\mathrm{AlH}_{3}$; this latter work is summarized below.

DSC plots from $\alpha, \beta$ and $\gamma-\mathrm{AlH}_{3}$ in the temperature range of $35-300^{\circ} \mathrm{C}$ ramped at a rate of $10^{\circ} \mathrm{C} / \mathrm{min}$ are shown in figure $1 \mathrm{a}$.
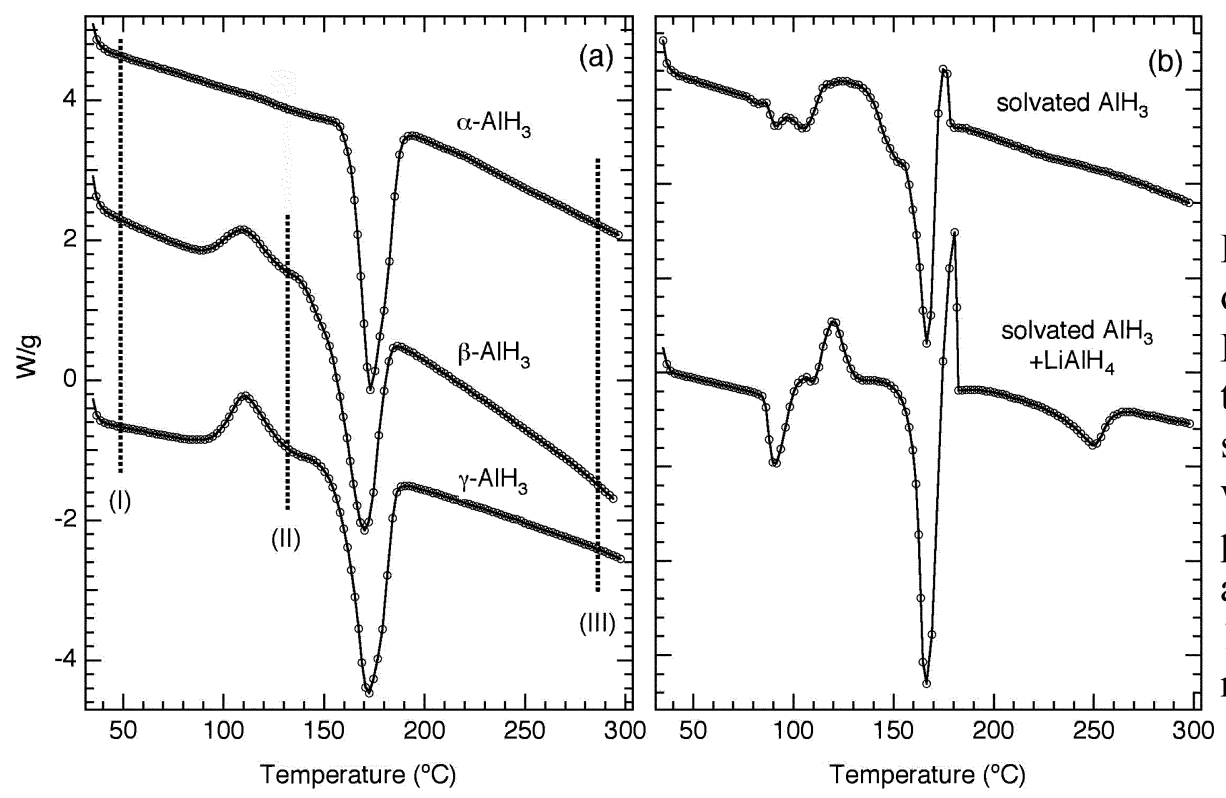

Figure 1. (a) DSC plots of $\alpha, \beta$, and $\gamma-\mathrm{AlH}_{3}$.

Dotted lines designate temperatures where ex situ diffraction patterns were acquired. (b) DSC plots of solvated $\mathrm{AlH}_{3}$ and solvated $\mathrm{AlH}_{3}+$ $1 / 4 \mathrm{LiAlH}_{4}$ ramped at a rate of $10^{\circ} \mathrm{C} / \mathrm{min}$. 


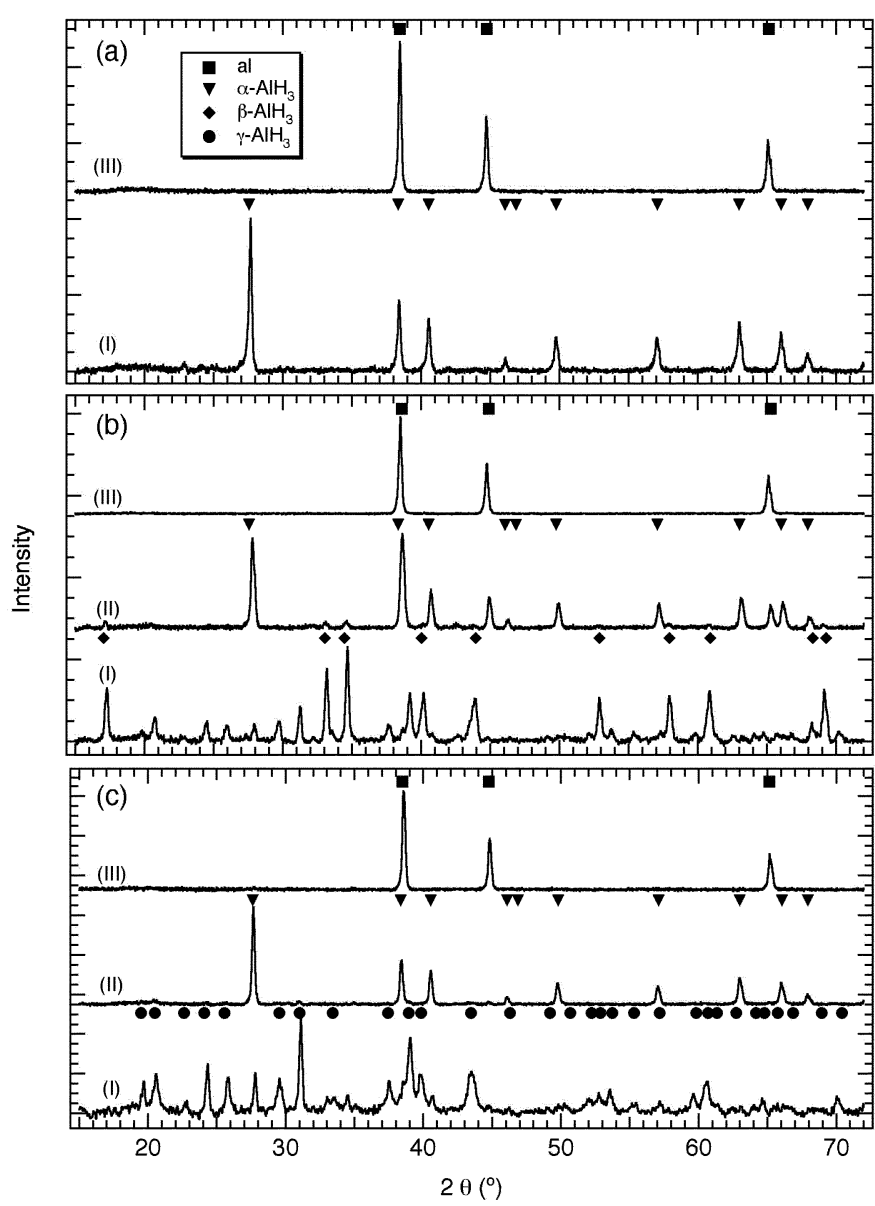

Figure 2. Ex situ x-ray diffraction from (a) $\alpha$ $\mathrm{AlH}_{3}$ (b) $\beta-\mathrm{AlH}_{3}$ and (c) $\gamma-\mathrm{AlH}_{3}$ acquired at room temperature before thermal treatment (I), after a temperature ramp to $130^{\circ} \mathrm{C}$ and after a temnerature ramn to $300^{\circ}$ (II).

The DSC trace from $\alpha-\mathrm{AlH}_{3}$ exhibits a single endothermic peak at around $170^{\circ} \mathrm{C}$ and is attributed to the decomposition of $\alpha$ $\mathrm{AlH}_{3}$ (reaction 1). This is confirmed by the ex situ $x$-ray diffraction patterns shown in figure 2a. Diffraction pattern II demonstrates that the $\alpha$ phase is completely decomposed to $\mathrm{Al}$ metal (and thereby $\mathrm{H}_{2}$ ). The measured formation enthalpy, calculated from the integration of the peak area, is $\Delta H_{f}=-9.9 \pm$ $0.4 \mathrm{~kJ} / \mathrm{mol} \mathrm{AlH}$ (Table I). This is similar to the enthalpy measured by Sinke et al. ${ }^{5}$ of $-11.4 \pm 0.8 \mathrm{~kJ} / \mathrm{mol} \mathrm{AlH} 3$ using calorimetry, and calculated values of Wolverton et al. [8] $\left(-6.95 \mathrm{~kJ} / \mathrm{mol} \mathrm{AlH}_{3}\right)$ and $\mathrm{Ke}$ et al. [9] $\left(-12.35 \mathrm{~kJ} / \mathrm{mol} \mathrm{Al} \mathrm{H}_{3}\right)$. The Gibbs free energy of formation, $\Delta G_{298 \mathrm{~K}}$, was calculated using the measured formation enthalpy and a $\Delta S$ of $130.7 \mathrm{~J} / \mathrm{K} \mathrm{mol} \mathrm{H}_{2}$, which is the entropy change associated with the transformation of hydrogen from disordered gas into an ordered solid, thus $\Delta G_{298 \mathrm{~K}}=48.5$ $\pm 0.4 \mathrm{~kJ} / \mathrm{mol} \mathrm{AlH}$ (Table I). This value yields an $\mathrm{H}_{2}$ equilibrium pressure of $5 \times 10^{5}$ bar at $298 \mathrm{~K}$, which is comparable to the value predicted by Claudy et al. [10] and considerably higher than the value measured by Baranowski et al. [6] at $423 \mathrm{~K}$.

The DSC plots from $\beta-\mathrm{AlH}_{3}$ and $\gamma$ $\mathrm{AlH}_{3}$ are also shown in figure 1a. In addition to the endothermic peak at $170^{\circ} \mathrm{C}$, the DSC trace exhibits a distinct exothermic peak at approximately $100^{\circ} \mathrm{C}$ for both phases. Diffraction patterns, acquired prior to thermal treatment, after a ramp to $130^{\circ} \mathrm{C}$ and after a ramp to $290^{\circ} \mathrm{C}$, are shown in figure $2 \mathrm{~b}$. Prior to thermal treatment, the $\beta$ phase is relatively pure, with a small amount of a $\gamma$ phase impurity as shown in figure $2 \mathrm{~b}$ (pattern I). After a ramp to $130^{\circ} \mathrm{C}$ the $\beta$ phase has almost completely transformed to $\alpha$ $\mathrm{AlH}_{3}$ with a small amount of $\mathrm{Al}$ metal and residual $\beta-\mathrm{AlH}_{3}$ (figure $2 \mathrm{~b}$ pattern II). A similar reaction was observed for $\gamma-\mathrm{AlH}_{3}$ (figure 2c pattern I), which also transforms to $\alpha-\mathrm{AlH}_{3}$ at around $100^{\circ} \mathrm{C}$ (figure $2 \mathrm{c}$ pattern II). In both cases, a temperature ramp to $290^{\circ} \mathrm{C}$ leads to the expected decomposition of the $\alpha$ phase (pattern III).

Table I: Formation energies and temperature onsets for $\alpha, \beta$ and $\gamma-\mathrm{AlH}_{3}$ showing transition enthalpy $\left(\Delta H_{0}\right)$ and temperature onset $\left(T_{0}\right)$, heat of formation for $\mathrm{Al}+3 / 2 \mathrm{H}_{2} \rightarrow \alpha-\mathrm{AlH}_{3}\left(\Delta H_{1}\right)$ and temperature onset $\left(T_{l}\right)$, total formation enthalpy $\left(\Delta H_{f}=\Delta H_{0}+\Delta H_{l}\right)$ and the Gibbs free energy $\left(\Delta \mathrm{G}_{f 298 \mathrm{~K}}=\Delta H_{f}-T \Delta S\right.$ where $\left.\Delta S=130.7 \mathrm{~J} / \mathrm{mol} \mathrm{K}\right)$.

\begin{tabular}{ccccccc}
\hline $\begin{array}{c}\text { Polymorph } \\
\text { (starting) }\end{array}$ & $\left.\begin{array}{c}\Delta \mathrm{H}_{0} \\
(\mathrm{~kJ} / \mathrm{mol} \mathrm{AlH}\end{array}\right)$ & $\begin{array}{c}\mathrm{T}_{0} \\
\left({ }^{\circ} \mathrm{C}\right)\end{array}$ & $\begin{array}{c}\Delta \mathrm{H}_{1} \\
(\mathrm{~kJ} / \mathrm{mol} \mathrm{AlH})\end{array}$ & $\begin{array}{c}\mathrm{T}_{1} \\
\left({ }^{\circ} \mathrm{C}\right)\end{array}$ & $\begin{array}{c}\Delta \mathrm{H}_{\mathrm{f}} \\
\left(\mathrm{kJ} / \mathrm{mol} \mathrm{AlH}_{3}\right)\end{array}$ & $\begin{array}{c}\Delta \mathrm{G}_{f 298 \mathrm{~K}} \\
\left(\mathrm{~kJ} / \mathrm{molAlH}_{3}\right)\end{array}$ \\
\hline$\alpha-\mathrm{AlH}_{3}$ & - & - & $-9.9 \pm 0.6$ & 162.1 & $-9.9 \pm 0.6$ & $48.5 \pm 0.6$ \\
$\beta-\mathrm{AlH}_{3}$ & $1.5 \pm 0.4$ & 91.0 & $-9.5 \pm 0.6$ & 157.1 & $-8.0 \pm 1.0$ & $50.5 \pm 1.0$ \\
$\gamma-\mathrm{AlH}_{3}$ & $2.8 \pm 0.4$ & 100.7 & $-9.9 \pm 0.6$ & 158.3 & $-7.1 \pm 1.0$ & $51.4 \pm 1.0$ \\
\hline
\end{tabular}


These results clearly demonstrate that the $\beta$ and $\gamma$ phases of $\mathrm{AlH}_{3}$ are unstable relative to the $\alpha$ phase and that the phase transitions take place readily at around $100^{\circ} \mathrm{C}$. The large endothermic peaks observed in both cases are due to the decomposition of the $\alpha$ phase product. The phase transition enthalpy $\left(\Delta H_{0}\right)$, heat of formation for $\alpha-\mathrm{AlH}_{3}\left(\Delta H_{1}\right)$ and the Gibbs free energy for the $\mathrm{AlH}_{3}$ polymorphs are shown in Table I; note that $\Delta H_{1}$ is essentially constant since it is for the same material. The measured formation enthalpy for $\alpha-\mathrm{AlH}_{3}$ is approximately -10 $\mathrm{kJ} / \mathrm{mol} \mathrm{AlH}_{3}$, which is consistent other experimental and calculated results. Since the $\gamma$ and $\beta$ phase transitions are exothermic they may occur spontaneously even at room temperature.

The DSC plots from solvated $\mathrm{AlH}_{3}$ and solvated $\mathrm{AlH}_{3}+\mathrm{LiAlH}_{4}$ over a temperature range of $35-300^{\circ} \mathrm{C}$ are shown in figure $1 \mathrm{~b}$. The DSC traces from etherated $\mathrm{AlH}_{3}$ are considerably more complicated than those from the nonsolvated material, exhibiting a number of overlapping endothermic and exothermic peaks. The small endothermic peak at $<100^{\circ} \mathrm{C}$ is attributed to the release of the associated solvent, $\left(\mathrm{C}_{2} \mathrm{H}_{5}\right)_{2} \mathrm{O}$. The first exothermic peak, due to the $\gamma \rightarrow \alpha$ transition, overlaps with this low temperature endothermic peak in the solvated material. However, with the addition of $\mathrm{LiAlH}_{4}$ the peaks become well separated and the release of the solvent occurs at a slightly lower temperature. As originally noted by Brower et al. [2], the addition of $\mathrm{LiAlH}_{4}$, or other complex metal hydride, lowers the desolvation temperature sufficiently to isolate the $\gamma$ or $\beta$ phases prior to decomposition.

\section{Decomposition Kinetics of $\mathrm{AlH}_{3}$}

$\underline{\text { Temperature Programmed Decomposition (TPD) of Aged } \alpha-\mathrm{AlH}_{3}}$

The decomposition rates for aged $\alpha-\mathrm{AlH}_{3}$ (Dow) were recently reported by Sandrock et al. [11] It was found that ball milling this material with LiH substantially decreased the inception of decomposition as shown in figure 3. The results of 4 experiments are shown using samples, which were ball milled for $1 \mathrm{~h}$ with varying amounts of $\mathrm{LiH}$. It was suggested by Sandrock et al. that the mechanism by which the kinetics were accelerated involved the formation of $\mathrm{LiAlH}_{4}$ on the $\mathrm{AlH}_{3}$ particle which serves as window for hydrogen passage into the gas phase. Supporting this contention was that $\mathrm{x}$-ray diffraction indicated the presence of $\mathrm{LiAlH}_{4}$ after ball milling. Further, the complex hydride $\mathrm{LiAlH}_{4}$ was also found to be an effective dopant. The alkali hydrides, $\mathrm{NaH}$ and $\mathrm{KH}$ also were active in this connection but not as effective as $\mathrm{LiH}$.

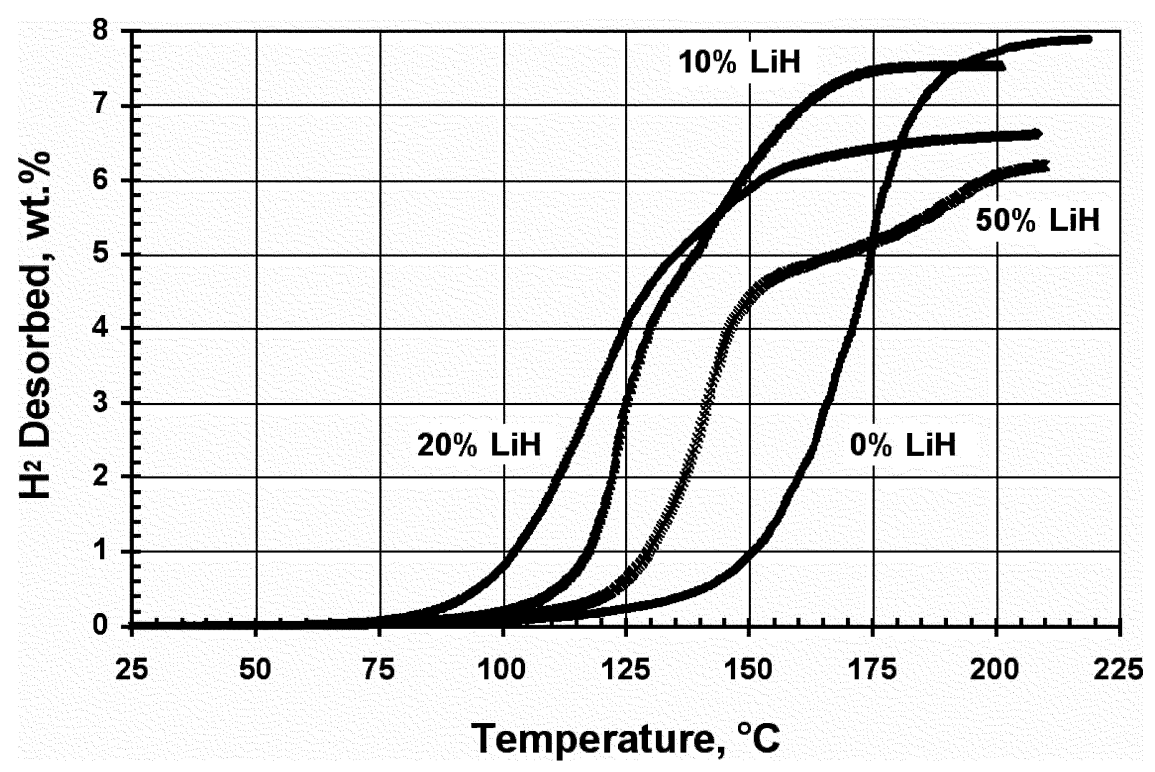

Figure 3. Effect of $\mathrm{LiH}$ doping on the TPD scans of one-hour ball milled $\mathrm{AlH}_{3}$ $\mathrm{LiH}$ mixtures [11]. $\mathrm{LiH}$ levels expressed in mol percent. Scan rate $=2^{\circ} \mathrm{C} / \mathrm{min}$. 
Isothermal kinetic measurements have been reported by Herley [12] in 1981 for the decomposition of $\alpha-\mathrm{AlH}_{3}$ (Dow material) and more recently by Graetz and Reilly [4] using freshly prepared $\alpha, \beta$ and $\gamma$ polymorphs. Plots of the fractional decomposition of the $\mathrm{AlH}_{3}$ polymorphs between $60^{\circ}$ and $140^{\circ} \mathrm{C}$ are shown in figure 4 . At temperatures of $100^{\circ} \mathrm{C}$ and above the decomposition occurs at similar rates for the three polymorphs. However, at $60^{\circ} \mathrm{C}$ the $\gamma$ phase exhibits rapid decomposition, while the decomposition rate is slower for the $\beta$ phase and considerably slower for the $\alpha$ phase. The shape of the $60^{\circ} \mathrm{C}$ decomposition curve of $\gamma-\mathrm{AlH}_{3}$ (specifically, the change in slope at $t \approx 80 \times 10^{3} \mathrm{~s}$ ) suggests the presence of two decomposition mechanisms. It is likely that a fraction of the $\gamma$ and $\beta$ polymorphs decompose directly to $\mathrm{Al}+$ $3 / 2 \mathrm{H}_{2}$ while another, larger fraction transforms to the $\alpha$ phase, which then decomposes. It is reasonable to assume that the direct decomposition of $\gamma-\mathrm{AlH}_{3}$ and $\beta-\mathrm{AlH}_{3}$ occurs more rapidly than the $\alpha$ phase due to the lower formation enthalpy. At higher temperatures $\left(\mathrm{T}>100^{\circ} \mathrm{C}\right)$, it is likely that the $\gamma$ and $\beta$ phases transform immediately to the $\alpha$ phase.

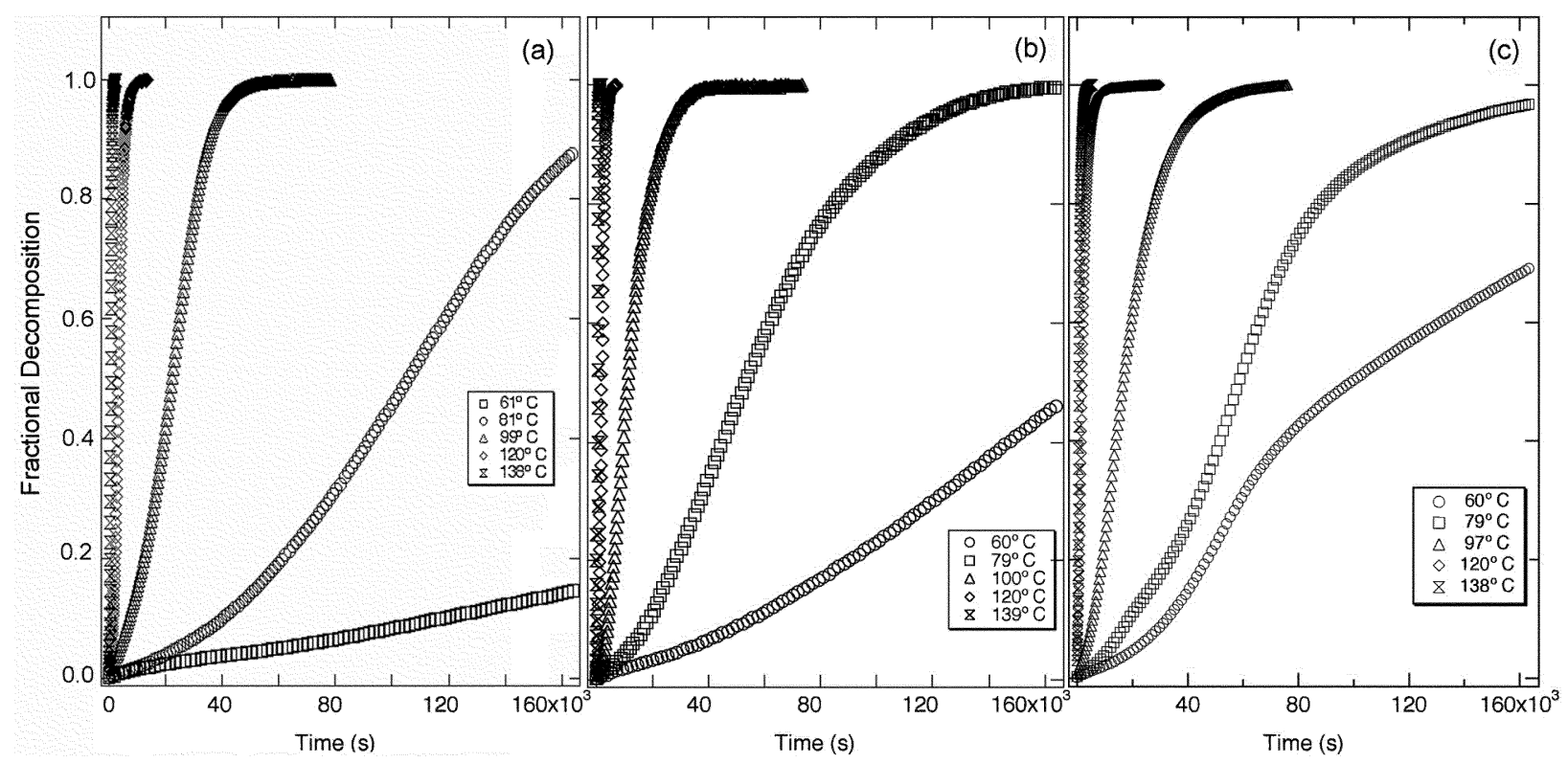

Figure 4. Isothermal decomposition of (a) $\alpha-\mathrm{AlH}_{3}$ (b) $\beta-\mathrm{AlH}_{3}$ and (c) $\gamma-\mathrm{AlH}_{3}$ between $60^{\circ}$ and $140^{\circ} \mathrm{C}$ plotted as fractional decomposition, $\alpha$, vs. $t$.

Since the kinetic data involving the $\beta$ and $\gamma$ phases appears to be affected by the phase transition to the $\alpha$ phase (especially at $T>100^{\circ} \mathrm{C}$ ) our kinetic analysis will be limited to the decomposition of $\alpha-\mathrm{AlH}_{3}$. In figure $4 \mathrm{a}$ we present a series of plots for $\mathrm{AlH}_{3}$ wherein the fraction reacted, $\alpha$ (hydrogen evolved/total hydrogen at time $t$ ) vs. time. The kinetic data were analyzed using a form of the Avrami-Erofeyev (A-E) equation, which can be generally applied to many nucleation and growth transformations. The equation may be written as follows:

$$
[-\ln (1-\alpha)]^{1 / n}=k t \text {, }
$$

where $n$ is a geometric factor and can have whole number values of 1,2 or 3 . A value of 1 indicates linear growth, 2 indicates two dimensional growth and 3 suggests three-dimensional growth. In the present case the data fit the A-E equation very well at $n=2$. This is demonstrated in figure 5 which shows a plot of $[-\ln (1-\alpha)]^{1 / n}$ vs. time. The plot is linear and the reaction rate constant, $k$, can be determined from the slope of a least squares fit to the data. 
The Arrhenius equation can be invoked to calculate the variation of $k$ as a function of temperature, $T$,

$$
k_{\mathrm{T}}=A \exp \left[-E_{\mathrm{a}} / R T\right]
$$

where $A$ is a pre-exponential parameter, $E_{\mathrm{a}}$ is the activation energy and $R$ is the universal gas constant. $E_{\mathrm{a}}$ and $A$ can be determined from the slope and intercept of a plot of $\ln k$ vs. $1 / T$ as shown in figure 6 . For $\alpha-\mathrm{AlH}_{3} E_{\mathrm{a}}$ was determined to be $102.2 \mathrm{~kJ} / \mathrm{mol}$ and $A$ to be $11.9 \times 10^{9}$. It

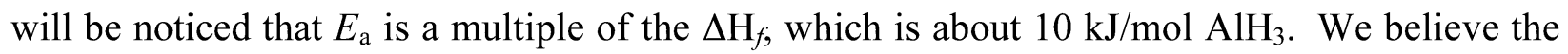
large activation energy measured may be attributed to a decomposition process involving an activated complex rather than individual molecules. Based upon the measured activation energy and known dissociation enthalpy for $\alpha-\mathrm{AlH}_{3}$ the complex consists of $\sim 9 \mathrm{AlH}_{3}$ molecules, or 1-2 unit cells. Although this is only one possible decomposition mechanism, it is reasonable to suggest that the conversion of $\alpha-\mathrm{AlH}_{3}$ to $\mathrm{Al}$ occurs in increments of whole unit cells.

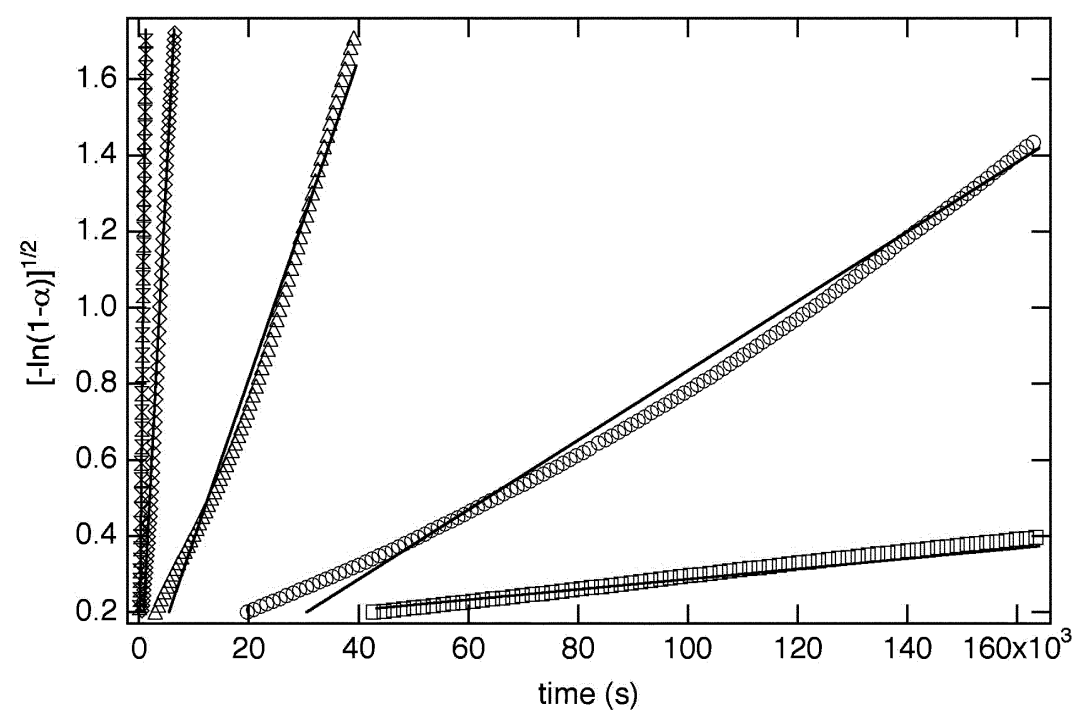

Figure 5. Decomposition of $\alpha$ $\mathrm{AlH}_{3}$ between $60^{\circ}$ and $140^{\circ} \mathrm{C}$ plotted as $[-\ln (1-\alpha)]^{1 / 2}$ vs. $t$. The solid line is a leastsquares fit to the region $0.04 \leq$ $\alpha \leq 0.95$.

The decomposition reaction rates measured for freshly synthesized $\alpha-\mathrm{AlH}_{3}$ are an order of magnitude greater at $60^{\circ} \mathrm{C}$ than those measured for the Dow material and the kinetic constants ( $A$ and $\left.E_{\mathrm{a}}\right)$ are considerably smaller than those measured by Herley et al. $\left(A=3.5 \times 10^{16}\right.$ and $E_{\mathrm{a}}=150.3 \pm 10.0 \mathrm{~kJ} / \mathrm{mol}$ ) [12]. Although it is likely that the decomposition of the Dow material is still limited by nucleation and growth, the differences in the kinetic rates can be attributed to the large particle size $(100 \mu \mathrm{m})$ and a passivation layer on the surface of the Dow material.

\section{Conclusions}

The thermodynamics and kinetics of the aluminum hydride polymorphs $\left(\alpha-\mathrm{AlH}_{3}, \beta-\mathrm{AlH}_{3}\right.$ and $\gamma-$ $\mathrm{AlH}_{3}$ ) were investigated. The decomposition of freshly synthesized $\mathrm{AlH}_{3}$ is controlled by nucleation and growth and not limited by diffusion through an oxide layer. We demonstrate that the $\beta$ and $\gamma$ phases are unstable with respect to the $\alpha$ polymorph. Thermal decomposition of the $\beta$ and $\gamma$ polymorphs typically occurs via a transition to the more stable $\alpha$ phase at around $100^{\circ} \mathrm{C}$ followed by the decomposition of the $\alpha$ phase to $\mathrm{Al}$ and $\mathrm{H}_{2}$. The transitions between polymorphs are exothermic and are therefore likely to occur spontaneously even at room temperature. In addition, a fraction of the $\gamma$ and $\beta$ polymorphs decompose directly to $\mathrm{Al}+\mathrm{H}_{2}$ at low temperature. The direct decomposition of the $\gamma$ and $\beta$ phases is faster than the $\alpha$ phase due to the lower total formation enthalpy. The measured formation enthalpy for $\alpha-\mathrm{AlH}_{3}$ is approximately $-10 \mathrm{~kJ} / \mathrm{mol}$ $\mathrm{AlH}_{3}$, which is consistent with other experimental and calculated results. 


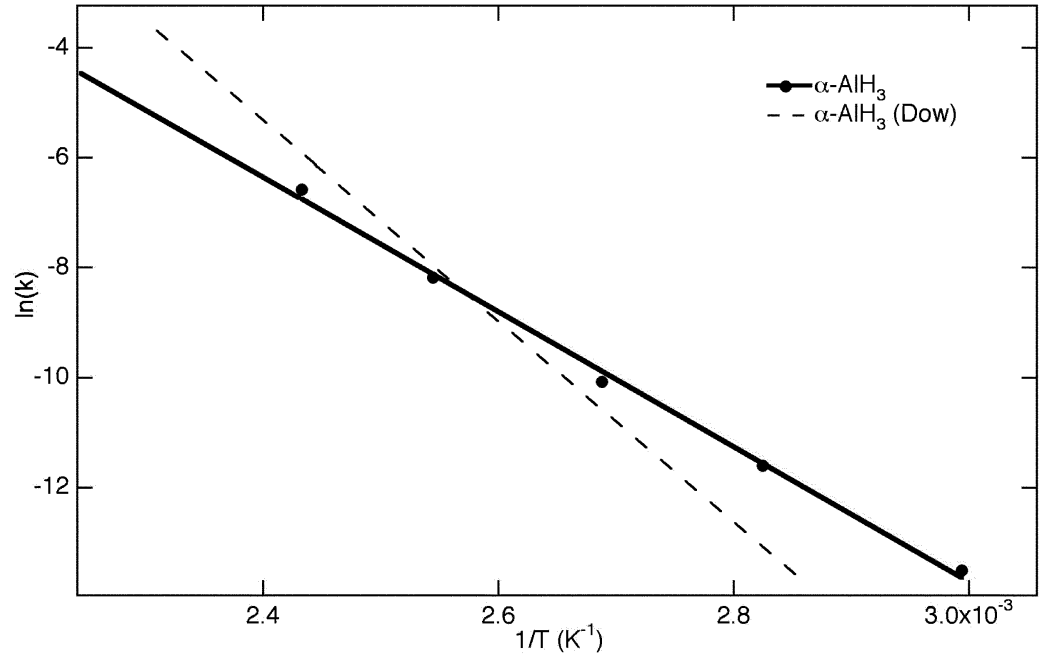

Figure 6. Arrhenius plots for aged $\alpha-\mathrm{AlH}_{3}$ (Dow) [12] and freshly prepared $\alpha-\mathrm{AlH}_{3}$. Reaction rates for aged $\alpha-\mathrm{AlH}_{3}$ were measured $135^{\circ} \mathrm{C}<T<$ $160^{\circ} \mathrm{C}$ and are extrapolated down to $T \sim 60^{\circ} \mathrm{C}$.

In general, the rapid low temperature kinetics and high energy density make $\mathrm{AlH}_{3}$ an unusual and promising hydrogen storage medium for a number of applications. However, the conventional organometallic synthesis is a costly procedure and $\mathrm{AlH}_{3}$ is not a reversible hydride at practical $\mathrm{H}_{2}$ pressures. Incorporating dopants or catalytic additives is not likely to produce the large thermodynamic changes required to substantially reduce the equilibrium pressure. Therefore, the utility of this material for automotive applications will depend upon the development of new techniques to regenerate $\mathrm{AlH}_{3}$ from the spent $\mathrm{Al}$ powder in a cost effective and energetically efficient manner.

\section{Acknowledgements}

This work was funded by the U.S. Department of Energy, Contract No. DE-AC02-98CH1-886.

\section{References}

[1] A. E. Finholt, A. C. Bond, and H. I. Schlesinger, J. Am. Chem., 69 (1947) 1199.

[2] F. M. Brower, N. E. Matzek, P. F. Reigler, H. W. Rinn, C. B. Roberts, D. L. Schmidt, J. A. Snover, and K. Terada. J. Am. Chem. Soc. 98 (1976) 2450.

[3] Turley, J.W. and Rinn, H. W., Inorg. Chem. 8 (1969) 18.

[4] J. Graetz and J. Reilly. J. Phys. Chem. B in press, 2005.

[5] Sinke, G. C.; Walker, L. C.; Oetting, F. L.; Stull, D. R. J. Chem. Phys., 47 (1967) 2759.

[6] B. Baranowski and M. Tkacz. Z. Phys. Chem. 135 (1983) 27.

[7] J. Graetz and J. Reilly. J. Alloys and Comp. submitted, 2005.

[8] C. Wolverton, V Ozolins, and M. Asta. Phys. Rev. B 69 (2004) 144109.

[9] X Ke, A. Kuwabara, and I. Tanaka. Phys. Rev. B 71 (2005) 184107.

[10] P. Claudy, B. Bonnetot, J. Etienne, and G. Turck. J. Therm. Anal. 8 (1975) 255.

[11] G. Sandrock, J. Reilly, J. Graetz, W. M. Zhou, J. Johnson, and J. Wegrzyn. Appl. Phys. A, 80 (2005) 687.

[12] P. J. Herley, O. Christoferson, and R. Irwin. J. Phys. Chem. 85 (1981) 1887. 